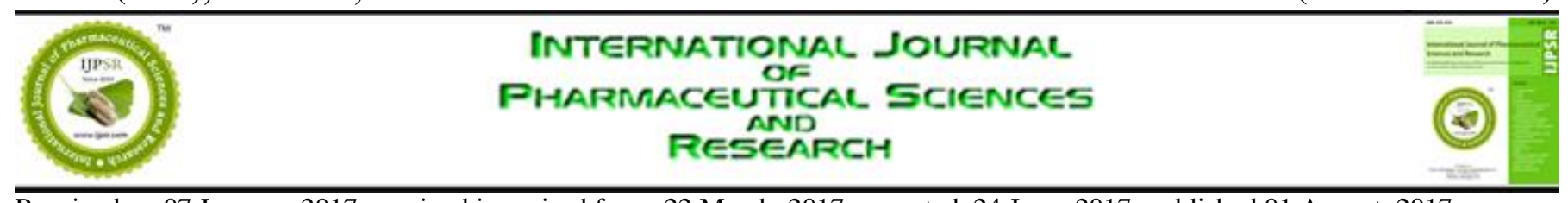

Received on 07 January, 2017; received in revised form, 22 March, 2017; accepted, 24 June, 2017; published 01 August, 2017

\title{
METHOD DEVELOPMENT AND VALIDATION FOR THE ESTIMATION OF PLERIXAFOR BY RP-HPLC METHOD IN BULK DRUG AND PHARMACEUTICAL DOSAGE FORM
}

\author{
S. V. Saibaba ${ }^{*}$ and P. Shanmuga Pandiyan
}

Department of Pharmacy, Mewar University, Chittorgarh - 312901, Rajasthan, India.

\section{Keywords:}

Plerixafor, RP-HPLC, Validation

\section{Correspondence to Author:}

\section{S. V. Saibaba}

Research Scholar,

Department of Pharmacy,

Mewar University, Chittorgarh

- 312901, Rajasthan, India.

E-mail: svsbaba70@gmail.com

\begin{abstract}
A simple, precise and accurate RP-HPLC method was developed for the determination of Plerixafor in bulk and pharmaceutical dosage forms. The estimation was carried out on Xterra RP $18(4.6$ x 250mm, $5 \mu \mathrm{m})$ column using a mixture of Methanol: Water $(50: 50 \% \mathrm{v} / \mathrm{v})$ as the mobile phase at a flow rate of $0.8 \mathrm{ml} / \mathrm{min}$, the detection was carried out at $215 \mathrm{~nm}$. The method was validated for linearity, accuracy, precision, specificity, limit of detection and limit of quantification and robustness as per ICH norms. The retention time of the Plerixafor was $5.481 \mathrm{~min}$. The method produce linear responses in the concentration range of $10-50 \mathrm{mg} / \mathrm{ml}$ with correlation coefficient $\left(\mathrm{r}^{2}\right)$ of 0.999 . The proposed method is useful for the estimation of plerixafor in its pure and injection dosage forms.
\end{abstract}

INTRODUCTION: Plerixafor (PRX) belongs to the class anticancer ${ }^{1}$. It is used to stimulate the release of stem cells from the bone marrow into the blood in patients with non-Hodgkin lymphoma and multiple myeloma ${ }^{2}$. These stem cells are then collected and used in autologous stem cell transplantation to replace blood-forming cells that were destroyed by chemotherapy ${ }^{3}$. Plerixafor has orphan drug status in the United States and European Union; it was approved by the U. S. Food and Drug Administration on December 15, 2008. Plerixafor inhibits the CXCR4 chemokine receptor and blocks binding to the marrow compartment of its cognate ligand, SDF-1alpha, which play a role in the trafficking and homing of human hematopoietic stem cells ${ }^{4-6}$.

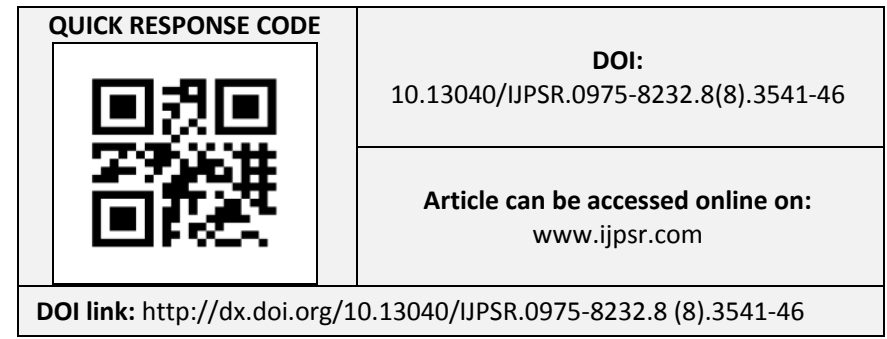

Plerixafor ${ }^{7}$ is chemically $1,1^{\prime}-[1,4$-phenylenebis (methylene)]bis [1, 4, 8, 11- tetraazacyclotetra decane] (Fig. 1). Literature survey revealed estimation of Plerixafor by only one HPLC method and no other methods have been reported for the determination of PRX in pharmaceutical dosage forms. ${ }^{8-10}$ In this present study an attempt was made to develop rapid and economical RP-HPLC method for the determination Plerixafor in pharmaceutical formulation with better accuracy, precision and sensitivity using $\mathrm{C} 18$ column.

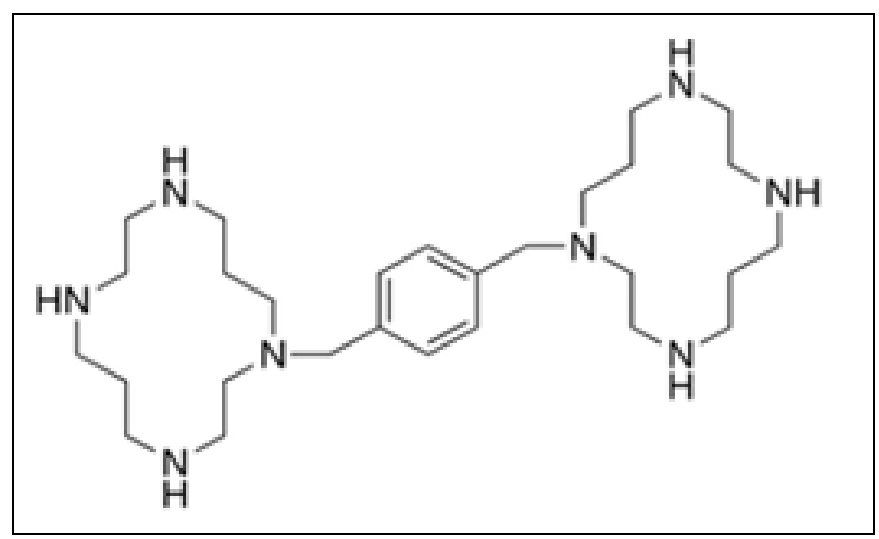

FIG. 1: STRUCTURE OF PLERIXAFOR 


\section{MATERIALS AND METHODS:}

Chemicals and Reagents: Plerixafor standard (purity $\geq 99.0 \%$ ) was obtained as gift sample from Sura Labs, Hyderabad. All chemicals and reagents used were HPLC grade. Acetonitrile (HPLC grade), Methanol (HPLC grade) were obtained from Merck (India). Plerixafor is available as single vial with brand names MOZOBIL, MOZOBIL DS. Chromatographic separation was achieved by using a WATERS Alliance HPLC system equipped with 2695 separation module, software: Empower 2, 996 photodiode array detector with C18 $(250 \mathrm{~mm} \times 4.6$ $\mathrm{mm}$ i.d., $5 \mu \mathrm{m}$ particle size) column maintained at $25^{\circ} \mathrm{C}$. The overall run time was $10 \mathrm{~min}$. and the flow rate was $0.8 \mathrm{~mL} \mathrm{m^{-1 }}$. $10 \mu \mathrm{L}$ of sample was injected into the HPLC system ${ }^{11-13}$.

\section{Preparation of Mobile phase, Standard Solution and Sample Solution:}

Mobile Phase: Accurately measured 500ml (50\%) of Methanol, $500 \mathrm{ml}$ of Water $(50 \%)$ and were mixed and degassed in a digital ultra-sonicator for 10 minutes and then filtered through $0.45 \mu$ filter under vacuum filtration. The Mobile phase was used as the diluents ${ }^{14-15}$.

Preparation of Standard Stock Solution: Stock solution was prepared by transferring 10mg of Plerixafor into $10 \mathrm{ml}$ of clean dry volumetric flasks add about $7 \mathrm{ml}$ of diluent and sonicate to dissolve and removal of air completely and make the volume upto the mark with diluent. Further pipette out $0.3 \mathrm{ml}$ of above Plerixafor stock solution into $10 \mathrm{ml}$ volumetric flask and dilute to the mark with diluent. Standard chromatogram is shown in Fig. 3 and result in Table 1a.

Preparation of Sample Solution: Take average weight of injection sample and weigh equivalent to $10 \mathrm{mg}$ of Plerixafor and transfer into $10 \mathrm{ml}$ volumetric flask, diluent was added to it and sonicate to dissolve and make the volume with diluent. Further pipette out $0.3 \mathrm{ml}$ of above Plerixafor stock solution into $10 \mathrm{ml}$ volumetric flask and dilute to the mark with diluent. Sample chromatogram is shown in Fig. 4 and result in Table $1 \mathbf{b}$.

Chromatographic Conditions: Chromatographic separation was performed at ambient temperature on a reverse phase Waters ODS (C18) column, 250 $\mathrm{mm} \times 4.6 \mathrm{~mm}$ i.d., $5 \mu \mathrm{m}$ particle size. The mobile phase used in this analysis consists of a mixture of methanol and water in the ratio of 50:50. The mobile phase was filtered, degassed before use. The flow rate was adjusted to $0.8 \mathrm{ml} / \mathrm{min}$, the detector wavelength was set at $215 \mathrm{~nm}$. The injector volume of standard and sample was $10 \mu \mathrm{l}$. The solution was injected and chromatograms were recorded. Calibration curve was constructed and regression equation was calculated for Plerixafor.

\section{RESULTS AND DISCUSSION: Method Validation:}

System Suitability: System performance parameters of HPLC method were determined by injecting standard solutions. Parameters such as number of theoretical plates $(\mathrm{N})$, tailing factor, Retention time (RT) were determined. The results were shown in (Table 1). From system suitability studies it is observed that \% RSD values are within the limit i.e. not more than 2 which indicates good performance of the system. The results are tabulated in Table 2.

Linearty: A series of solutions were prepared using plerixafor working standard solution at a concentration levels from $10-50 \mu \mathrm{g} / \mathrm{ml}$ and the peak area response of all solutions are measured. A graph was plotted against the Concentration $(\mu \mathrm{g} / \mathrm{ml})$ on $\mathrm{X}$-axis versus area / response on $\mathrm{Y}$-axis. The detector response was found to be linear with a correlation coefficient of 0.999 . Linearity graph is shown in Fig. 5, linearity results are tabulated in Table $4^{16-19}$.

Specificity: It is the ability to asses unequivocally the analyte in the presence of components that may be expected to be present. Excipients that are commonly used were spiked into a pre weighed quantity of drugs. Appropriate dilutions were injected into chromatographic system and the quantities of the drugs were determined. The results are tabulated in Table 3 .

Precision: Precision studies were performed (Method, Day to day). The results are reported in term of Relative standard deviation. The repeatability studies were carried out by estimating response of 6 different concentrations of Plerixafor and reported in terms of \% RSD, \% RSD was 0.3, for method precision it was 0.4 and for day to day 
precision it was 0.24 . The results are tabulated in Table 5, 5a and 5b.

Accuracy: Accuracy of the method was determined by calculating the recovery of Plerixafor by the spiked method. Known quantity of Plerixafor was added to a pre-determined sample solution and the amount of Plerixafor was estimated by measuring peak areas. Mean \% recovery values are within the limit (limit is 98102\%). Accuracy data was presented in Table 6.

LOD and LOQ Limits: The level of detection (LOD) and level of Quantification (LOQ) were conducted on the basis of standard deviation of the response and the slope. The LOD and LOQ for Plerixafor were found to be $1.03 \mu \mathrm{g}$ and $3.14 \mu \mathrm{g}$ respectively.

Robustness: Robustness is a measure of its capacity to remain unaffected by small, but deliberated variation in the method parameters and gives an indication of its reliability during normal The robustness was performed for the flow rate variations from $0.7 \mathrm{ml} / \mathrm{min}$ to $0.9 \mathrm{ml} / \mathrm{min}$ and mobile phase ratio variation from more organic phase to less organic phase ratio for Plerixafor. The method is robust only in less flow condition and the method is robust even by change in the Mobile phase $\pm 5 \%$. The standard and samples of Plerixafor were injected by changing the conditions of chromatography. There was no significant change in the parameters like resolution, tailing factor, asymmetric factor, and plate count. The method passed robustness test with well \% RSD. Robustness data was presented in Table 7.

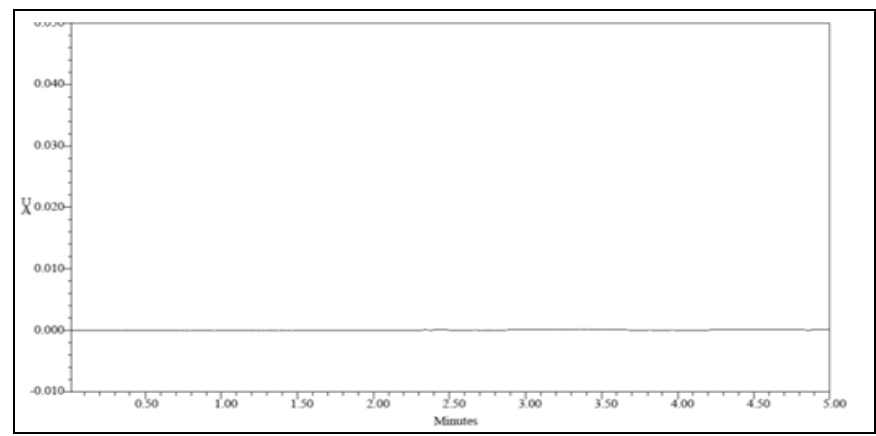

FIG. 2: CHROMATOGRAM SHOWING BLANK
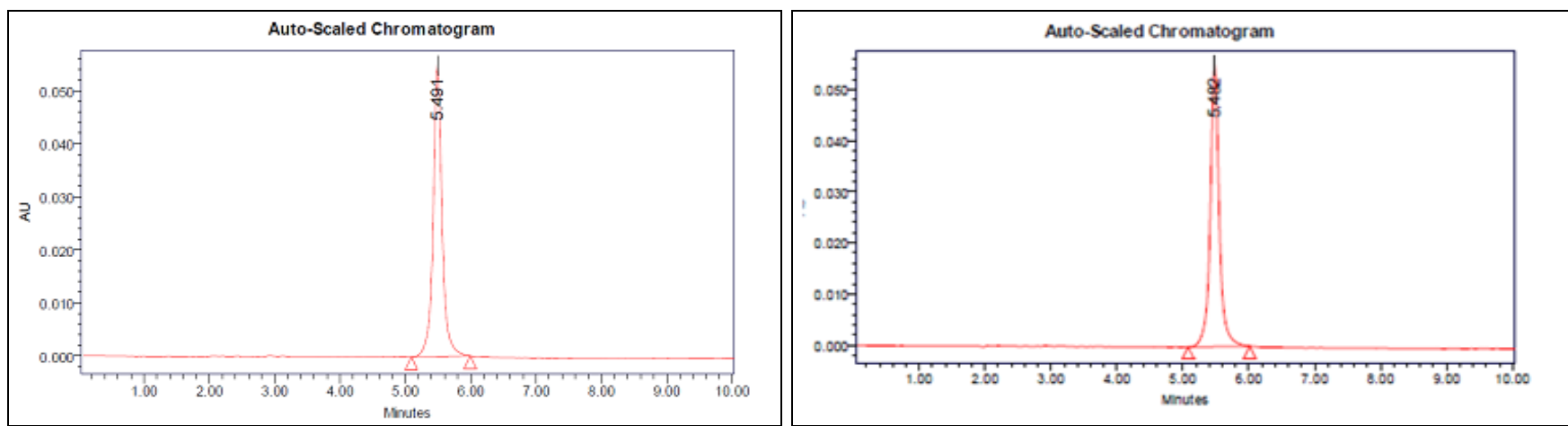

FIG. 3: OPTIMIZED CHROMATOGRAM (STANDARD)

FIG. 4: OPTIMIZED CHROMATOGRAM (SAMPLE)

TABLE 1(A): OPTIMIZED CHROMATOGRAM (STANDARD)

\begin{tabular}{ccccccc}
\hline S. no & Name & RT & Area & Height & USP Tailing & USP Plate Count \\
\hline 1 & Plerixafor & 5.481 & 530529 & 55564 & 1.03 & 9222 \\
\hline
\end{tabular}

TABLE 1(B): OPTIMIZED CHROMATOGRAM (SAMPLE)

\begin{tabular}{ccccccc}
\hline S. no & Name & RT & Area & Height & USP Tailing & USP Plate Count \\
\hline 1 & Plerixafor & 5.482 & 522448 & 54873 & 1.06 & 9186 \\
\hline
\end{tabular}

TABLE 2: SYSTEM SUITABILITY

\begin{tabular}{clccccc}
\hline S. no & Name & RT & Area & Height $(\boldsymbol{\mu}$ V) & USP Plate Count & USP Tailing \\
\hline 1 & Plerixafor & 5.395 & 514884 & 54648 & 9011 & 1.07 \\
2 & Plerixafor & 5.484 & 530529 & 55564 & 9222 & 1.05 \\
3 & Plerixafor & 5.491 & 521608 & 54920 & 9148 & 1.04 \\
4 & Plerixafor & 5.482 & 522448 & 54873 & 9186 & 1.06 \\
5 & Plerixafor & 5.491 & 521608 & 54920 & & \\
Mean & & 522215.4 & & & \\
Std. Dev. & & 5560.066 & & \\
\% RSD & & 1.06 & & \\
\hline
\end{tabular}


TABLE 3A: SPECIFICITY ASSAY (STANDARD)

\begin{tabular}{clcccccc}
\hline S. no & Name & RT & Area & Height & Tailing & USP Plate Count & Injection \\
\hline 1 & Plerixafor & 5.427 & 530023 & 56127 & 1.03 & 9118 & 1 \\
2 & Plerixafor & 5.430 & 531649 & 56299 & 1.05 & 9364 & 2 \\
3 & Plerixafor & 5.443 & 533969 & 55991 & 1.05 & 9186 & 3 \\
\hline
\end{tabular}

TABLE 3B: SPECIFICITY ASSAY (STANDARD)

\begin{tabular}{clcccccc}
\hline S. no & Name & RT & Area & Height & Tailing & USP Plate Count & Injection \\
\hline 1 & Plerixafor & 5.453 & 534995 & 55722 & 1.05 & 9124 & 1 \\
2 & Plerixafor & 5.462 & 532954 & 56050 & 1.03 & 9207 & 2 \\
3 & Plerixafor & 5.466 & 533577 & 56095 & 1.03 & 9235 & 3 \\
\hline
\end{tabular}

\section{Linearity:}

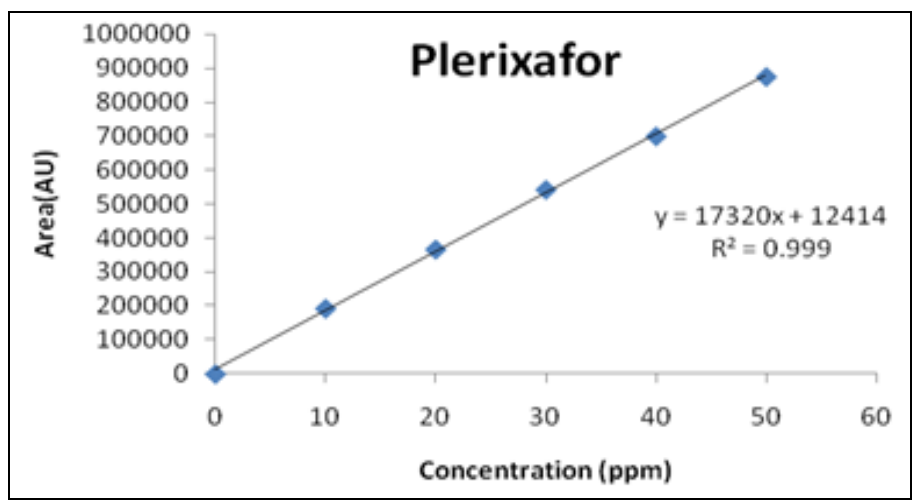

FIG. 5: CALIBRATION CURVE OF PLERIXAFOR

TABLE 4: LINEARITY DATA

\begin{tabular}{ccc}
\hline Concentration Level (\%) & Conc. $(\mathbf{m g} / \mathbf{m l})$ & Avg. Peak Area \\
\hline 33 & 10 & 192423 \\
66 & 20 & 366108 \\
100 & 30 & 541715 \\
133 & 40 & 698851 \\
166 & 50 & 873452 \\
\hline
\end{tabular}

TABLE 5: RESULTS OF PRECISION

\begin{tabular}{ccccccc}
\hline S. no & Peak name & RT & Area & Height & USP Plate Count & USP Tailing \\
\hline 1 & Plerixafor & 5.352 & 516091 & 54804 & 9009 & 1.1 \\
2 & Plerixafor & 5.346 & 518821 & 54903 & 9131.5 & 1.1 \\
3 & Plerixafor & 5.293 & 519536 & 55996 & 9071.7 & 1 \\
4 & Plerixafor & 5.284 & 519881 & 56012 & 9075.7 & 1 \\
5 & Plerixafor & 5.319 & 519895 & 55577 & 8987.3 & 1 \\
Mean & & & 518844.8 & & & \\
Std. dev & & & 1599.873 & & & \\
\% RSD & & & 0.3 & & & \\
\hline
\end{tabular}

Intermediate Precision:

TABLE 5(A): RESULTS OF INTERMEDIATE PRECISION

\begin{tabular}{ccccccc}
\hline S. no & Peak name & RT & Area & Height & USP Plate Count & USP Tailing \\
\hline 1 & Plerixafor & 5.352 & 516091 & 54804 & 9009.0 & 1.1 \\
2 & Plerixafor & 5.346 & 518821 & 54903 & 9131.5 & 1.1 \\
3 & Plerixafor & 5.293 & 519536 & 55996 & 9071.7 & 1.0 \\
4 & Plerixafor & 5.284 & 519881 & 56012 & 9015.7 & 1.0 \\
5 & Plerixafor & 5.319 & 519895 & 55577 & 8987.3 & 1.0 \\
6 & Plerixafor & 5.306 & 522826 & 55808 & 9070.5 & 1.0 \\
Mean & & & 519408.3 & & & \\
Std. dev & & & 2216.8 & & & \\
$\%$ RSD & & 0.4 & & & \\
\hline
\end{tabular}


TABLE 5(B): RESULTS OF INTERMEDIATE PRECISION DAY 2

\begin{tabular}{ccccccc}
\hline S. no & Peak name & RT & Area & Height & USP Plate Count & USP Tailing \\
\hline 1 & Plerixafor & 5.274 & 518217 & 55506 & 8953.2 & 1.1 \\
2 & Plerixafor & 5.306 & 518821 & 54903 & 9131.5 & 1.1 \\
3 & Plerixafor & 5.306 & 518821 & 54903 & 9131.5 & 1.1 \\
4 & Plerixafor & 5.274 & 518217 & 55506 & 8953.2 & 1.1 \\
5 & Plerixafor & 5.352 & 516091 & 54804 & 9009.0 & 1.1 \\
6 & Plerixafor & 5.319 & 519895 & 55577 & 8987.3 & 1.0 \\
Mean & & & 518343.7 & & & \\
Std. dev & & 1262.452 & & & \\
\% RSD & & 0.24 & & & \\
\hline
\end{tabular}

TABLE 6: ACCURACY

\begin{tabular}{cccccc}
\hline $\begin{array}{c}\text { \% Conc. (at } \\
\text { specification Level) }\end{array}$ & Area & $\begin{array}{c}\text { Amount Added } \\
(\mathbf{p p m})\end{array}$ & $\begin{array}{c}\text { Amount Found } \\
\text { (ppm) }\end{array}$ & $\begin{array}{c}\text { \% } \\
\text { Recovery }\end{array}$ & $\begin{array}{c}\text { Mean } \\
\text { Recovery }\end{array}$ \\
\hline $50 \%$ & 269654.7 & 15 & 14.85 & $100 \%$ & \\
$100 \%$ & 529274 & 30 & 29.84 & $99.40 \%$ & $99.90 \%$ \\
$150 \%$ & 794469.3 & 45 & 45.15 & $100.30 \%$ & \\
\hline
\end{tabular}

\section{Robustness:}

TABLE 7: RESULTS FOR ROBUSTNESS

\begin{tabular}{ccccc}
\hline Parameter used for sample analysis & Peak Area & RT & Theoretical plates & Tailing factor \\
\hline Actual Flow rate of $0.8 \mathrm{~mL} / \mathrm{min}$ & 530529 & 5.491 & 9222 & 1.03 \\
Less Flow rate of $0.7 \mathrm{~mL} / \mathrm{min}$ & 566441 & 5.599 & 9364 & 1.02 \\
More Flow rate of $0.9 \mathrm{~mL} / \mathrm{min}$ & 459187 & 4.576 & 7559 & 0.98 \\
Less organic phase & 24366 & 7.415 & 12009 & 1 \\
More organic phase & 93382 & 4.576 & 8274 & 1.07 \\
\hline
\end{tabular}

CONCLUSION: In the present investigation, a simple, sensitive, precise and accurate RP-HPLC method was developed for the quantitative estimation of Plerixafor in bulk drug and pharmaceutical dosage forms. This method was simple, since diluted samples are directly used without any preliminary chemical derivatisation or purification steps. Plerixafor was freely soluble in ethanol, methanol and sparingly soluble in water. Methanol: Water (50:50\% v/v) was chosen as the mobile phase. The solvent system used in this method was economical. The \% RSD values were within 2 and the method was found to be precise. The RP-HPLC method is more sensitive, accurate and precise compared to the Spectrophotometric methods. This method can be used for the routine determination of Plerixafor in bulk drug and in Pharmaceutical dosage forms.

ACKNOWLEDGEMENT: I am thankful to the Sura Pharma labs, Hyderabad for providing gift sample of Plerixafor and I am very much thankful to the principal of KVK College of pharmacy and secretary of Kennedy education society, Hyderabad for guidance, encouragement and providing laboratory facilities.

\section{REFERENCES:}

1. Kealey and Haines PJ: Analytical Chemistry, $1^{\text {st }}$ edition, Bios Publisher 2002; 1-7.

2. Wait $A B$ and Smith FJ: Chromatographic Methods, $5^{\text {th }}$ edition, Kluwer Academic Publisher 1996; 1-2.

3. Uy GL and Cashen AF: Plerixafor, a CXCR4 antagonist for the mobilisation of haemopoetic stem cells, Expert opin Biol Ther 2008; S(11): 1797-1804.

4. Stewart DA, Smith C, Macfarland C and Calendra G: pharmacokinetics and pharmacodynamics of Plerixafor in patients with Blood marrow Transplant 2009; 15(1): 3946.

5. Reddy H, Kumar BR and Murthy S: Robust and Rugged Stability indicating HPLC method for the determination of plerixafor and its related impurities in drug substances, journal of chromatographic science 2015; 1-11.

6. Annapurna MM, Saipavankumar B, Goutham SVS and Venkatesh B: Stability indicating HPLC and derivative spectrophotometric methods for Plerixafor. Drug invention today 2012 ; 4(9): 465-469.

7. The merck index, an encyclopedia of Chemical Drug and Biologicals, Eds, $14^{\text {th }}$ Ed, published by merck reasearch Laboratories, Division of merck and Co. inc., White house station, NJ 2006.

8. ICH validation of analytical procedures: Text and Methodology Q2 (R1), International Conference on Hormonization 2005.

9. Weston A and Brown P: HPLC Principle and Practice, ${ }^{1 \text { st }}$ edition, Academic press 1997; 24-37.

10. Kazakevich Y and Lobrutto R: HPLC for Pharmaceutical Scientists, $1^{\text {st }}$ edition, Wiley Interscience A John Wiley and Son, Inc., Publication 2007; 15-23. 
11. Chromatography, (online). URL:http://en.wikipedia.org/ wiki/Chromatography.

12. Meyer VR: Practical High-Performance Liquid Chromatography, $4^{\text {th }}$ Ed. England, John Wiley and Sons Ltd 2004; 78.

13. Sahajwalla CG: A new drug development, Marcel Dekker Inc., New York 2004; 141: 421-426.

14. Introduction to Column. (Online),URL:http://amitpatel745. topcities.com/index_files/study/column care.pdf
15. Detectors used in HPLC (online )URL:http://wiki.answers. com/Q/What_detectors_are_used_in_HPLC

16. Detectors (online),URL:http://hplc.chem.shu.edu/NEW/H PLC_Book/Detectors/det_uvda.html

17. Detectors (online),URL:http://www.dionex.com/enus/web docs/64842-31644-02_PDA-100.pdf

18. Detectors (online),URL:http://www.ncbi.nlm.nih.gov/pub $\mathrm{med} / 8867705$.

19. Detectors (online),URL:http://www.chem.agilent.com/Libr ary/applications/59643559.pdf.

How to cite this article:

Saibaba SV and Pandiyan PS: Method development and validation for the estimation of Plerixafor by RP-HPLC method in bulk drug and pharmaceutical dosage form. Int J Pharm Sci Res 2017; 8(8): 3541-46.doi: 10.13040/IJPSR.0975-8232.8(8).3541-46.

All @ 2013 are reserved by International Journal of Pharmaceutical Sciences and Research. This Journal licensed under a Creative Commons Attribution-NonCommercial-ShareAlike 3.0 Unported License.

This article can be downloaded to ANDROID OS based mobile. Scan QR Code using Code/Bar Scanner from your mobile. (Scanners are available on Google Playstore) 